\title{
The Ore and Gangue Mineralogy of the Newly Discovered Federation Massive Sulfide Deposit, Central New South Wales, Australia ${ }^{+}$
}

\author{
Khalid Schellen 1, Ian T. Graham 1,*, Adam McKinnon 2, Karen Privat ${ }^{1,3}$ and Christian Dietz ${ }^{4}$ \\ 1 School of Biological, Earth, and Environmental Sciences, UNSW Sydney, Sydney, NSW 2052, Australia; \\ khalidschellen@gmail.com (K.S); k.privat@unsw.edu.au (K.P.) \\ 2 Aurelia Metals Limited, Level 17, 144 Edward Street, Brisbane, QLD 4000, Australia; \\ adam.mckinnon@aureliametals.com.au \\ 3 Electron Microscope Unit, Mark Wainwright Analytical Centre, UNSW Sydney, \\ Sydney, NSW 2052, Australia \\ 4 Central Science Laboratory, University of Tasmania, Hobart, TAS 7001, Australia; \\ Christian.dietz@utas.edu.au \\ * Correspondence: i.graham@unsw.edu.au; Tel.: +61-435-296-555 \\ † Presented at the 2nd International Electronic Conference on Mineral Science, 1-15 March 2021; \\ Available online: https://iecms2021.sciforum.net/.
}

Citation: Schellen, K.; Graham, I.T.; McKinnon, A.; Privat, K.; Dietz, C. The Ore and Gangue Mineralogy of the Newly-Discovered Federation Massive Sulfide Deposit, Central New South Wales, Australia. Environ. Sci. Proc. 2021, 6, 29. https://doi.org/10.3390/ iecms2021-09348

Academic Editor: Paul Sylvester

Published: 25 February 2021

Publisher's Note: MDPI stays neutral with regard to jurisdictional claims in published maps and institutional affiliations.

Copyright: $(\subseteq 2021$ by the authors. Licensee MDPI, Basel, Switzerland. This article is an open access article distributed under the terms and conditions of the Creative Commons Attribution (CC BY) license (http://creativecommons.org/licenses/by/4.0/).

\begin{abstract}
The newly discovered Federation deposit, with a resource estimate of $2.6 \mathrm{Mt} @ 7.7 \% \mathrm{~Pb}$, $13.5 \% \mathrm{Zn}, 0.8 \mathrm{~g} / \mathrm{t} \mathrm{Au}$, and $9 \mathrm{~g} / \mathrm{t} \mathrm{Ag}$, lies $10 \mathrm{~km}$ south of the Hera deposit within the Cobar Basin of the Lachlan Orogen. Located just north of the Erimeran Granite contact and between the Lower Amphitheatre Group and underlying shallow marine Mouramba Group Roset Sandstone, the host siltstones and sandstones have been brecciated, intensely silicified, and chloritized close to mineralization. Oriented in an overall east-northeast strike and with a steep south-southeast dip, the siltstones mainly comprise quartz, clinochlore, biotite, and muscovite. Federation also has highly fragmented zones with breccia and vein-fill of calcite. The main ore mineralization includes sphalerite and galena, with lesser chalcopyrite, pyrrhotite, pyrite, gold, and very rare meneghinite. Mineralization occurs within silicified veins and breccias of $\mathrm{Zn}-\mathrm{Pb}$ sulfides, which generally grade to moderate veining of sulfides with $\mathrm{Pb}$ and $\mathrm{Cu}$ dominant sulfides, as well as minor veining of base metals associated with visible gold. Mineralization throughout the deposit is fairly simple, with a low diversity of minerals. Iron concentration varies throughout the deposit, decreasing towards the center. Observations of massive sphalerite with gradations of red to honeycomb yellow indicate the transition from high $\mathrm{Fe}(7-10 \%)$ to low Fe (2-5\%) within the coarse sulfide assemblages over a very short distance. Within the main mineralized corridor, fibrous amphibole inclusions within galena/sphalerite assemblages are observed at $251 \mathrm{~m}$, as well as epidote associated with sulfides at $573 \mathrm{~m}$. Other ore-associated gangue minerals include ilmenite, siderite, scheelite, magnetite, apatite, and rutile.
\end{abstract}

Keywords: Federation deposit; Cobar Basin; mineralization; gold; base metal sulfides; mineralogy

\section{Introduction}

The Federation deposit is located $10 \mathrm{~km}$ south of the active Hera mine near the town of Nymagee, in central New South Wales, Australia (Figure 1). Past exploration by various companies failed to return significant mineralization results in the area. In mid-2019, a pole-dipole induced polarization (IP) geophysical survey was conducted by Aurelia Metals, returning a significant chargeability anomaly at the deposit [1]. Current drilling indicates a mineralized zone extending to a depth of over $600 \mathrm{~m}$ and over a strike-length of $460 \mathrm{~m}$. An initial mineral resource estimate of $2.6 \mathrm{Mt} @ 7.7 \% \mathrm{~Pb}, 13.5 \% \mathrm{Zn}, 0.8 \mathrm{~g} / \mathrm{t} \mathrm{Au}$, and $9 \mathrm{~g} / \mathrm{t}$ Ag was reported in June 2019 [2]. Mineralization varies through the deposit with a 
steeply dipping high-grade mineralized corridor in the northeastern section (Figure 2a), expanding out to several other steeply dipping vein breccia and massive sulfide lenses along a broad corridor with a northeast-southwest strike (Figure $2 b$ ).

The Cobar Basin comprises Silurian to Devonian sequences that vary in intensity of deformation and metamorphism stages (Figure 1) and is host to numerous mines and deposits, mainly Cobar-type structurally controlled sediment-hosted copper-gold and leadzinc deposits. During the late Silurian to early Devonian (440-400 Mya) deformation, cycles in the Lachlan Orogen mainly involving crustal extension and compression led to the formation of four deep-water troughs and intracratonic basins within the Cobar Basin [3]. As the Cobar Basin is considered to be one of the most economically significant regions in NSW [4], understanding the ore and gangue mineralogy of the Federation deposit will provide a further understanding of geological interpretations and resource estimates, as well as extending the operation of the nearby processing plant at Hera by feeding the ore from Federation.

Many mines and deposits within the Cobar Basin have gone through several phases of exploration history, leading to an increase in overall knowledge of the basin and a classification of Cobar-type deposits as epigenetic high sulfide gold-base metal type deposits [5]. Most of these deposits adhere to the criteria of a 'Cobar-type' deposit [6], including multiple ore lenses within the deposit, significant variation in metal ratios between nearby lodes, alignment of orebodies to regional cleavage, mineralization during basin inversion in the Early Devonian (440-400 Mya), lower greenschist metamorphism, and the presence of common gangue minerals including quartz, chlorite, carbonates, and albite. While the Federation deposit currently adheres to the criteria of a typical Cobar-type deposit, its unusually low copper and high gold content are shared with the nearby Hera mine, though it lacks the high temperature skarn stage of the latter [7].

The Federation deposit lies on the eastern boundary of the Cobar Basin, between the Mouramba Groups Roset Sandstone and overlying the Lower Amphitheatre Group, just north of the Erimeran Granite surface boundary [2]. Lying immediately west of the NNWtrending Rookery Fault (Figure 1), the Federation consists of a structurally controlled, sediment-hosted deposit containing silicified and brecciated sandstones and siltstones arranged into ENE-NE trending lodes (Figure 2b).

Due to its recent discovery, little is known about the geology of the deposit, especially regarding its host sequence, ore and gangue mineralogy, and the gold distribution, grain size, chemistry, and association with other minerals. This study presents details on the mineralogy of the host rocks, ore mineralization, and gangue, along with petrographic analysis of the host rock and mineralized samples through the collection and analysis of recently collected drill core samples. It has utilized petrographic analysis, $\mathrm{X}$-ray diffraction (XRD) analysis, pXRF/pXRD analysis, sulfur isotope analysis, and scanning electron microscope (SEM)/Electron Probe MicroAnalyser (EPMA) analysis.

\section{Materials and Methods}

The main diamond drill core samples and intervals investigated were FDD078 (530$625 \mathrm{~m})$, FRCD050 (330-368 m), FRCD062 (311-360 m), FRCD066 (308-317 m), and FRCD068 (243-292 m). Samples were selected to provide a range of the ore and gangue mineralization, along with the unmineralized host assemblage, in an attempt to provide a representation of the deposit as a whole. The locations and resources for these drill holes are shown in Figure 2a. Mineral species were identified and confirmed through petrographic analysis (transmitted and reflected light microscopy), XRD analysis, SEM analysis, and EPMA analysis. These analyses were all undertaken within the UNSW Mark Wainwright Analytical Centre, while sulfur isotope analyses were completed at the Central Science Laboratory, University of Tasmania. 


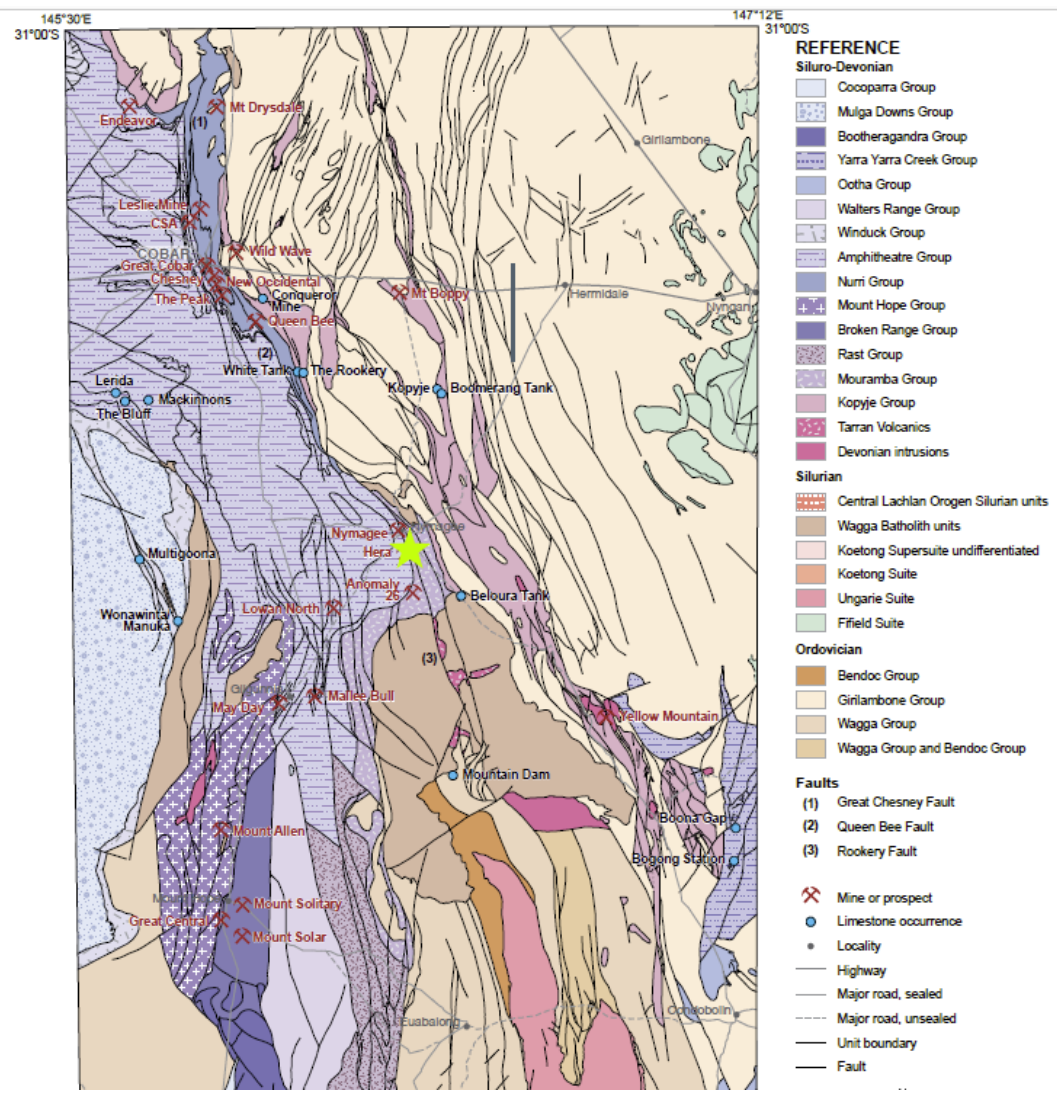

Figure 1. Regional geological map of the Cobar Basin, with the location of the Federation deposit and Hera mine indicated by the green star (modified from [7]).

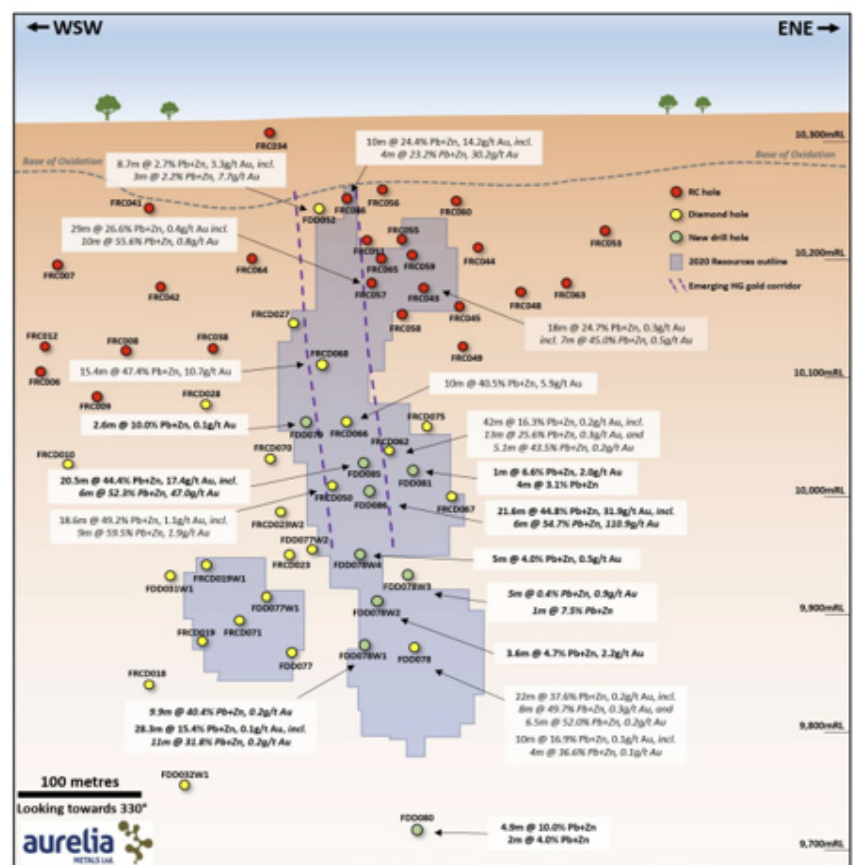

(a)

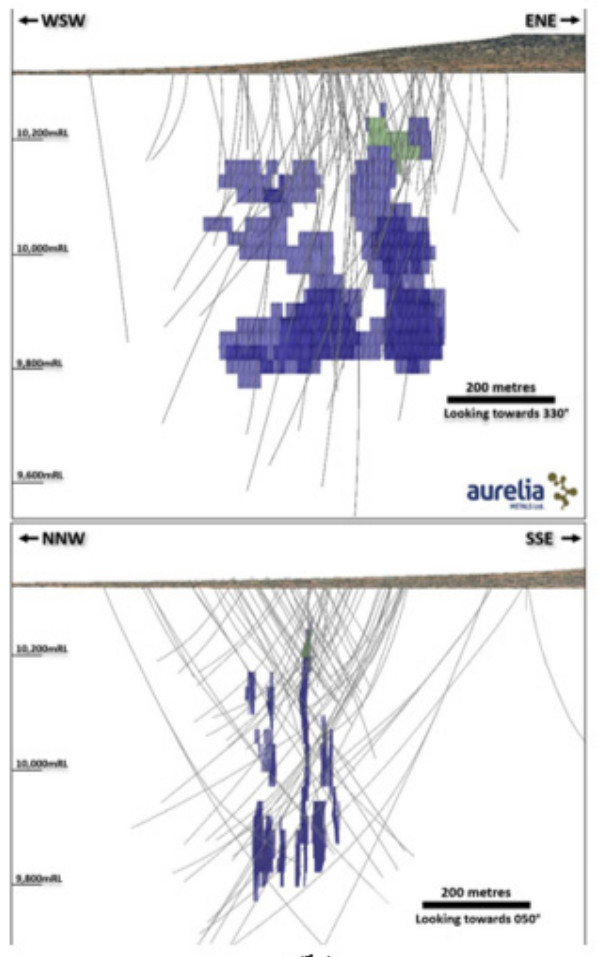

(b)

Figure 2. Cross- and long-sectional views of the Federation deposit: (a) long section of the high grade mineralized corridor in the north eastern section of the deposit with selected drill intercepts [8]; (b) The overall long- (top) and cross- (bottom) sectional model of the Federation deposit [2]. 
A total of 131 samples were crushed and mounted into $20 \mathrm{~mm}$ aluminum holders for lab XRD analysis using the PANalytical Empyrean II XRD machine, operated at $45 \mathrm{kV}$ and $40 \mathrm{~mA}$ and analyzed from 3-70 $2 \theta$ using the PIXcel ${ }^{\mathrm{ID}}$ detector with a step size of $0.013^{\circ} 2 \theta$. Resultant XRD patterns were then studied using X-plot software to identify the contained mineralogy. In total, 18 samples were chosen for polished mounts and were then investigated under reflected light using a Leica DM2500P polarizing microscope. EPMA analyses were made using the JEOL JXA-8500F Hyperprobe at $20 \mathrm{kV}$ for the sulfides and $15 \mathrm{kV}$ for the silicates, carbonates, oxides, and phosphates. Sulfur stable isotopes were measured with flash combustion isotope ratio mass spectrometry using the Elementar varioPYRO cube coupled to the Isoprime100 mass spectrometer. Abundances were reported in delta (d) values as the deviation from the conventional CDT (Canyon Diablo Troilite) standard in parts per mil (\%o).

\section{Results}

\subsection{Ore Mineralization and Distribution}

The modelled lenses with significant mineralization currently extend to a depth of over $600 \mathrm{~m}$ and a strike length of $460 \mathrm{~m}$ [2]. Mineralization is epigenetic in nature and hosted in fine-grained sandstones and siltstones, which have been silicified and brecciated. It is strongly structurally controlled, with several vein breccia and massive sulfide lenses steeply dipping in the center of a broad corridor of sulfide and quartz vein stockwork mineralization with a northeast-southwest strike (Figure 2b). Mineralization in the upper parts dominantly occurs as silica-sulfide infill within silicified veins and breccias of $\mathrm{Zn}-\mathrm{Pb}$ sulfides (Figure 3a) and progresses downwards towards zinc-rich (55-65 wt\%) massive sulfides and sulfide breccia base-metal mineralization associated with intense black chlorite alteration (Figure 3b) and visible gold. Iron concentration varies throughout the deposit, decreasing towards the center of the deposit. Observations of massive sphalerite with gradations of red to honeycomb yellow over only a few centimeters indicates a rapid transition from high Fe (7-10 wt\%) to low Fe (2-5 wt \%) within the coarse sulfide assemblages (Figure 4a). Coarse gold grains were only observed as visible grains in the cores (Figure $4 \mathrm{~b}$ ) during this study from parts of the high-grade northeastern mineralized corridor in holes FDD078W2 (531 m), FRCD050 (356-365 m), FRCD066 (312 m), and FRCD068 (248-252 m) (Figure 2a).

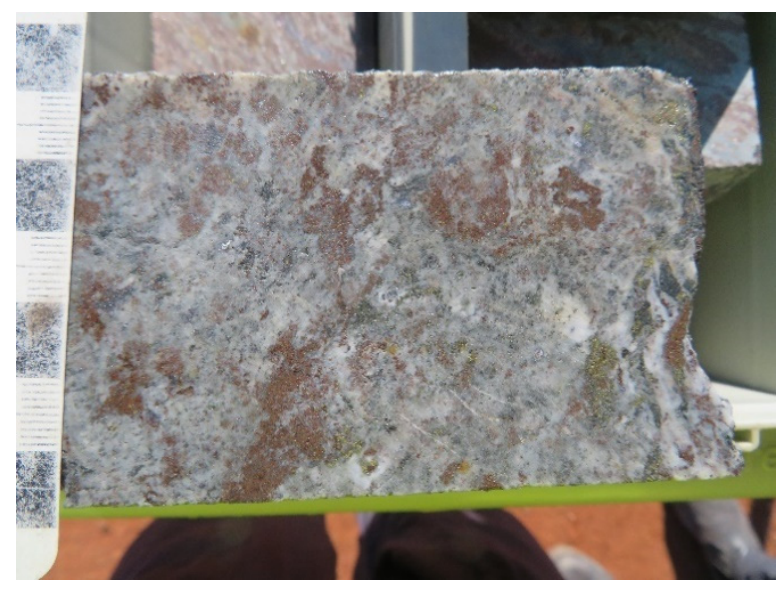

(a)

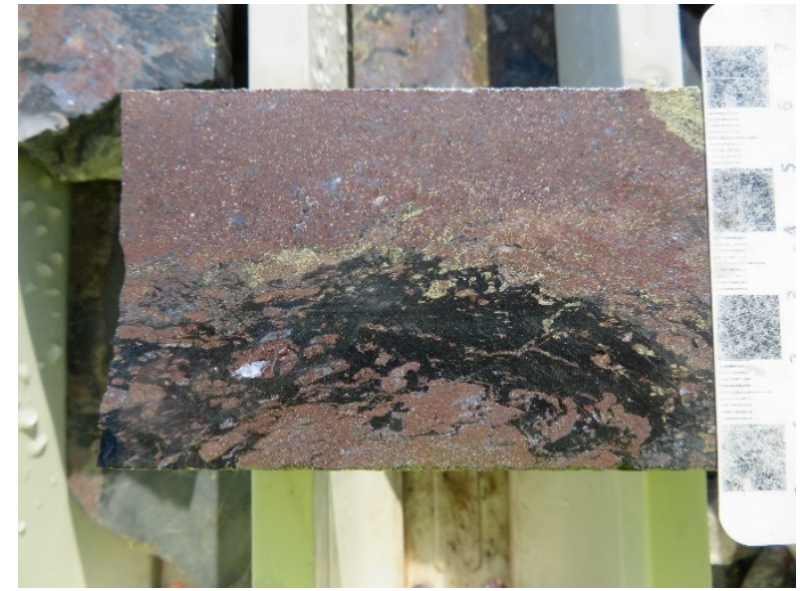

(b)

Figure 3. Selected mineralogical features within the Federation deposit: (a) Heavily silicified zone with high iron sphalerite, galena, and chalcopyrite from drill hole FRCD050 (362.85 m); (b) massive sulfides with intense black chlorite from drill hole FRCD050 (348.5 m). 


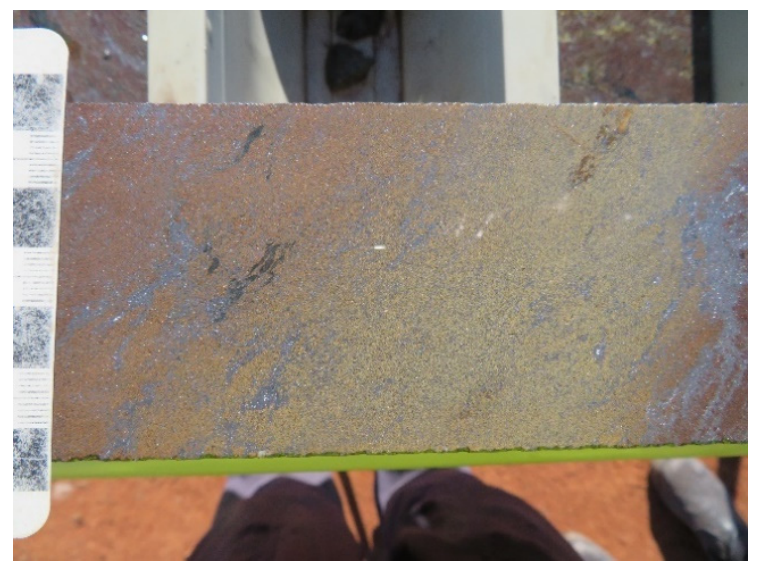

(a)

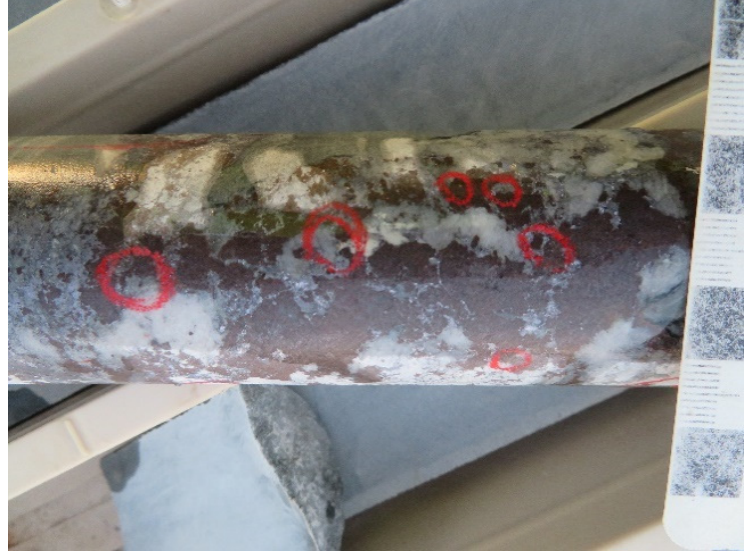

(b)

Figure 4. Selected mineralogical features within the Federation deposit: (a) Visible gradation of red to honeycomb yellow sphalerite, indicating transition from high (red) to low (yellow) iron composition from drill hole FRCD050 (363.8 m); (b) visible coarse gold grains circled in red from drill hole FDD078W2 (531.3 m).

\subsection{Mineralogy of the Host-Rocks, Ore, and Gangue}

XRD analyses of the host rocks within the Federation show that they mostly consist of quartz, chlorite, muscovite, phengite, biotite, calcite, fluorapatite, ilmenite, albite, and rutile (Table 1). Further analyses through EMPA detected additional accessory minerals, including magnetite, Mn-bearing ankerite, Ca-siderite, titanite, and orthoclase. There are two phases of chlorite alteration, with clinochlore being much more abundant. Its euhedral morphology and overprinting relationships indicate that this clinochlore is associated with a later stage of alteration (Figure 5a). An Al-bearing chamosite appears intergrown with the sulfides and is often overprinted by other minerals, indicating an association with an earlier phase (Figure 5b). The presence of several calcite veins and its abundance through the host rock, as found in the XRD analyses, suggest a role in the fragmentation and brittleness of the host rocks, particularly in the deeper parts (530-630 $\mathrm{m}$ ) of drill hole FDD078.

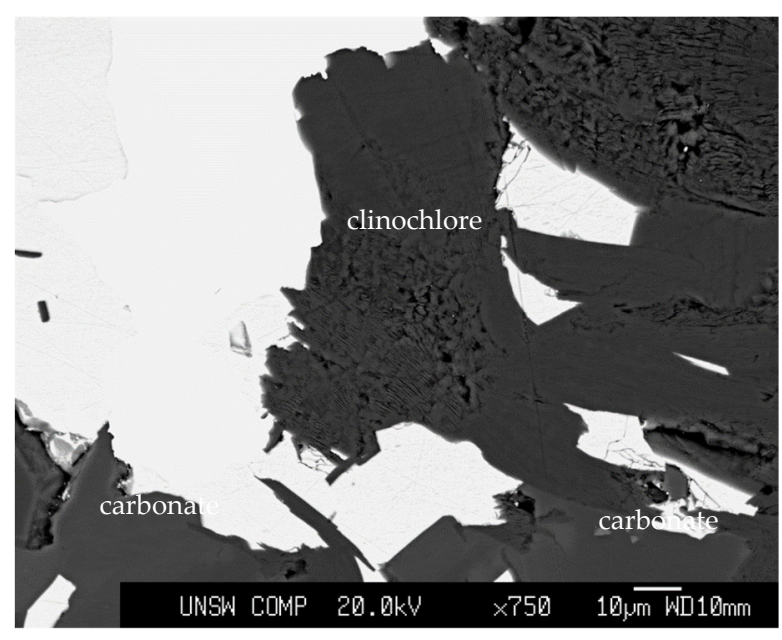

(a)

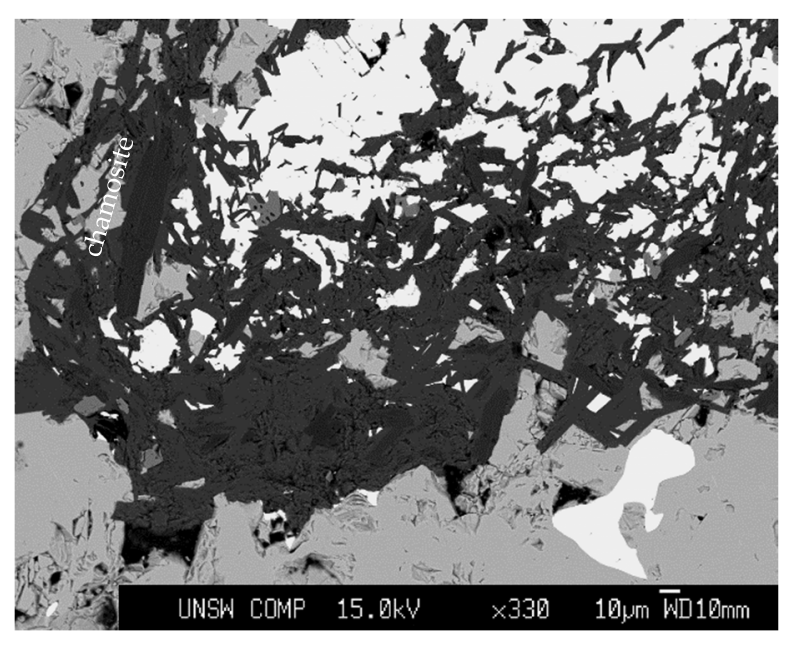

(b)

Figure 5. SEM chlorite features within the Federation deposit: (a) Euhedral-subhedral clinochlore overprinting surrounding carbonates from drill hole FRCD062 (343 m); (b) intergrown Al-bearing chamosite with sulfides from drill hole FRCD062 (322 m). 
Table 1. List of ore and gangue minerals identified during this study.

\begin{tabular}{cccccc}
\hline Sulfide Minerals & $\begin{array}{c}\text { Relative } \\
\text { Abundance }\end{array}$ & $\begin{array}{c}\text { Gangue } \\
\text { Minerals }\end{array}$ & $\begin{array}{c}\text { Relative } \\
\text { Abundance }\end{array}$ & Gangue Minerals & $\begin{array}{c}\text { Relative } \\
\text { Abundance }\end{array}$ \\
\hline Sphalerite & Major & $\begin{array}{c}\text { Quartz } \\
\text { Clinochlore }\end{array}$ & $\begin{array}{c}\text { Major } \\
\text { Major }\end{array}$ & $\begin{array}{c}\text { Siderite } \\
\text { Magnetite }\end{array}$ & Trace \\
Galena & Major & Chamosite & Major & Ankerite & Trace \\
Chalcopyrite & Major & Muscovite & Major & Scheelite & Trace \\
Pyrrhotite & Major & Calcite & Major & Epidote & Trace \\
Pyrite & Minor & Fluorapatite & Minor & Talc & Trace \\
Arsenopyrite & Minor & Rutile & Minor & Gypsum & Trace \\
Gold & Minor & Ilmenite & Minor & Orthoclase & Trace \\
Meneghinite & Trace & Biotite & Minor & Albite & Trace \\
& & Titanite & Trace & Ferro-eckermannite & Trace \\
\hline
\end{tabular}

The main ore mineralogy at the Federation is fairly simple and similar to other deposits within the Cobar Basin [9], comprising sphalerite and galena intergrowths with chalcopyrite, minor pyrrhotite and pyrite (Figure 6a,b), and gold. This assemblage appears to have formed in two separate stages, with an earlier, coarser phase exhibiting cuspate-lobate boundaries between the sphalerite, galena, and chalcopyrite (Figure 6a) and a later fine-grained event associated with quartz gangue (Figure 6b).

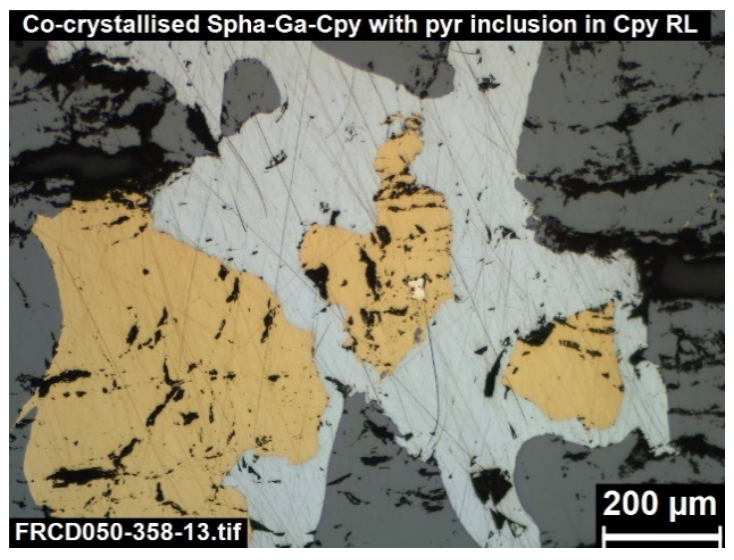

(a)

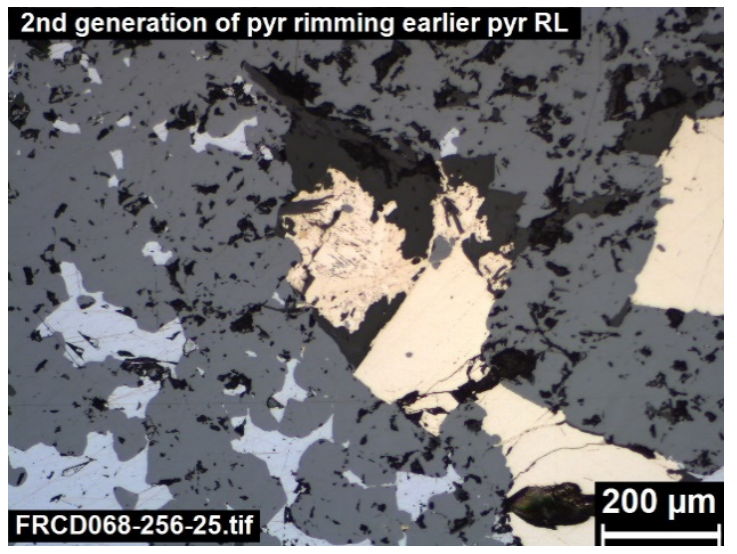

(c)

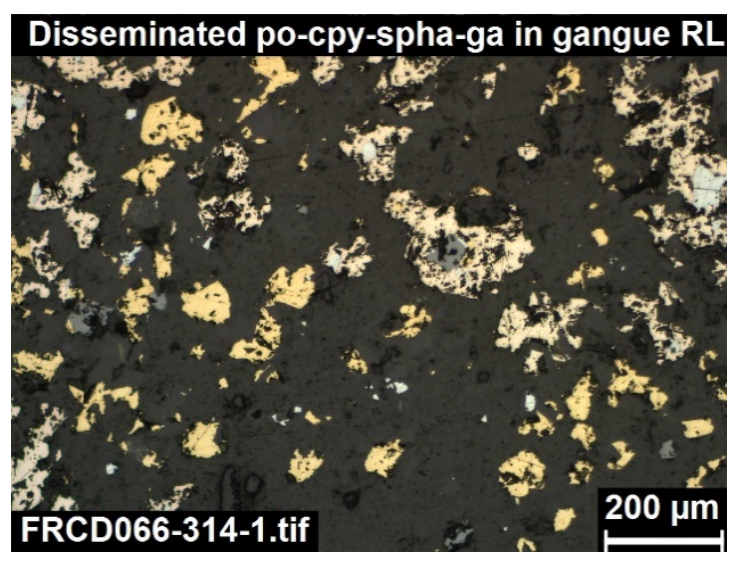

(b)

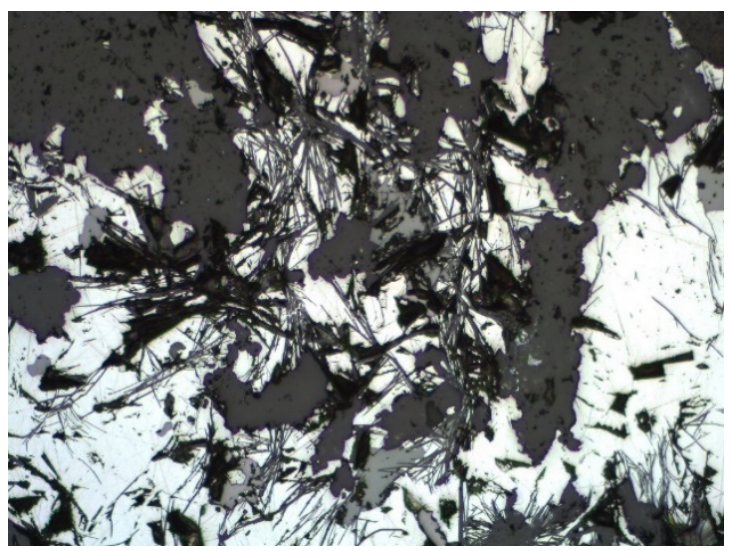

(d)

Figure 6. Reflected light microscope observations of ore mineralogy features within the Federation deposit: (a) Intergrowth texture of sphalerite, galena, and chalcopyrite, with small pyrite inclusions from drill hole FRCD050 (358 m); (b) fine grained pyrrhotite, chalcopyrite, sphalerite, and galena in gangue quartz from drill hole FRCD066 (314 m); (c) two generations of pyrite, with brecciated pyrite (II) rimming the earlier euhedral pyrite below the drill hole FRCD068 (256 m); (d) fibrous amphibole inclusions in galena and sphalerite from drill hole FRCD068 $(251 \mathrm{~m})$. 
The pyrrhotite and pyrite also appear to be associated with two separate mineralisation stages, as indicated by: (1) euhedral pyrrhotite crystals sometimes being replaced by chalcopyrite or pyrite and euhedral pyrite inclusions in sulfides and (2) massive pyrrhotite seen rimming other sulfides associated, with the second main mineralization stage and a finer grained subhedral and brecciated pyrite usually overgrown over the earlier pyrite (Figure 6c). Other observed sulfides include arsenopyrite, which is associated with pyrite, and very rare meneghinite (a complex sulfosalt mineral found in hydrothermal veins and associated with other common sulfides). A single observation of fibrous amphibole inclusions within sulfides was also observed (Figure 6d) and identified to be a potassic ferro-eckermannite in drill hole FRCD068 at a downhole depth of $251 \mathrm{~m}$.

The gold in the Federation shows little correlation to other metals, mostly visible as discrete grains in parts of the high grade northeastern mineralised corridor in holes FDD078W2 (531 m), FRCD050 (356-365 m), FRCD066 (312 m), and FRCD068 (248-252 m) (Figure 2a). Using Spearman's correlation, the assay data for gold shows little correlation to the other metals within the deposit. Gold was not observed in any of the thin sections or polished mounts.

Other selected elemental correlations were made with the company assay data using Spearman's correlation coefficients $(\mathrm{n}=1400) . \mathrm{Pb}$ and $\mathrm{Zn}$ were well correlated with a coefficient of 0.82 , as indicated by the dominant sphalerite and galena intergrowth in the Federation. $\mathrm{Cu}$ and $\mathrm{Zn}$ also contained moderate correlation with a factor of 0.43 , also indicated by moderate observations of chalcopyrite, sphalerite, and galena intergrowths (Figure 6a). The $\mathrm{Cu}$ and Fe had a low correlation with each other of 0.31, while Fe and $\mathrm{Zn}$ had almost zero correlation.

Alteration within the deposit is mainly in the form of chloritization, with the primary chlorite mineral being clinochlore and a secondary chamosite. Phyllic alteration is also present throughout, mostly as the phase phengite. Carbonate alteration is mostly present as calcite throughout the deposit, with accesory Mn-bearing ankerite being present in some of the mineralised lenses. A full list of minerals identified in this study can be found in Table 1.

\subsection{Isotope Analyses}

Six samples of sphalerite from varying locations in the deposit were sent for sulfur isotope analysis, giving a limited range of $\delta^{34} S$ values from 2.31 to 3.45 . One sample was analyzed from FRCD062 at a downhole depth of $357 \mathrm{~m}$, with a value of 3.45, two samples from FRCD066 had downhole depths of 310-312 m, with values of 2.62 and 2.31, and three samples from FRCD068 had downhole depths of 251, 254, and $256 \mathrm{~m}$, with similar values of $2.59,2.57$, and 2.59 .

\section{Discussion and Conclusions}

Presently, there have been no published studies on the Federation deposit, and thus, the results from this study will hopefully contribute to the understanding of geological controls on alteration and mineralization in similar deposits. The isotope sulfur data collected during this study contained a range of sulfur isotope values from 2.31 to $3.45 \delta^{34} \mathrm{~S}$. According to Downes and Poulson [10], this narrow range of values suggest that the supply of sulfur came from reservoirs primarily containing magmatic sulfur.

Though the nearby Hera mine was originally classified as being a Cobar-type deposit, it contains a number of features that contrast to this type of deposit, such as the presence of high-temperature skarn gangue mineral assemblages [7,11-13] and unusually low copper and high gold content. While Federation lies $10 \mathrm{~km}$ south of Hera and shares a similar high gold content, low $\delta^{34} S$ values with several of Heras lodes, and some similar mineral assemblages, including common sphalerite-galena intergrowths and widespread chlorite alteration, the overall mineralogy is less variable. On average, sulfur isotopes are lower at the Federation, suggesting a closer proximity to the theorized intrusion 
responsible for the high temperature skarn gangue mineral assemblage at Hera. Federation also contains far more pyrite than at Hera. Skarn alteration within the Federation characterized by potassic ferro-eckermannite is highly localized in occurrence in drill hole FRCD068 at a downhole depth of $251 \mathrm{~m}$. To date, the Federation primarily contains lowtemperature alteration assemblages, whereas Hera additionally contains high-temperature skarn alteration assemblages.

The results add to our overall knowledge on structurally controlled sediment-hosted $\mathrm{Au}-\mathrm{Pb}-\mathrm{Zn}-\mathrm{Cu}$ deposits worldwide, as well as placing important constraints on the existing genetic models for these deposits. More research will have to be done to determine the associations and further instances of skarn alteration within Federation, as well as determining any association between the gold and other metals.

Author Contributions: K.S. collected the samples, analyzed, and interpreted some of the data used for this project and wrote the manuscript. I.T.G. supervised the project, provided technical input and petrographic analyses, and assisted with SEM/EPMA analyses. A.M. co-supervised the project, provided technical input, and arranged access to the deposit, as well as funding for the project. K.P. coordinated all SEM and EPMA analyses. C.D. carried out the sulfur isotope analyses. All authors have read and agreed to the published version of the manuscript.

Funding: This research was funded by Aurelia Metals Limited.

Institutional Review Board Statement: Not appliable.

Informed Consent Statement: Not appliable.

Data Availability Statement: Not appliable.

Acknowledgments: We would like to thank Aurelia Metals Limited for funding this UNSW research project on the Federation deposit and all of the geologists who have so far worked on the Federation for their helpful advice. The authors acknowledge the facilities and the scientific and technical assistance of Microscopy Australia at the Electron Microscope Unit (EMU) within the Mark Wainwright Analytical Centre (MWAC) at UNSW Sydney.

Conflicts of Interest: The authors declare no conflict of interest.

\section{References}

1. Aurelia Metals Ltd. Discovery of High. Grade Mineralisation at the Federation Prospect., South. of Hera. 6 May 2019 ASX Announcement. 2019. Available online: https://www2.asx.com.au/markets/trade-our-cash-market/announcements.ami (accessed on 20 October 2020).

2. Aurelia Metals Ltd. Maiden Federation Resource Estimate. 9 June 2020 ASX Announcement. 2020. Available online: https://www2.asx.com.au/markets/trade-our-cash-market/announcements.ami (accessed on 20 October 2020).

3. Glen, R.A. Inverted transtensional basin setting for the gold and copper base metal deposits at Cobar, New South Wales. Austral. J. Geol. Geophys. 1991, 12, 13-24.

4. Tyson, R. High Grade Base Metals in the Cobar Basin; Diggers and Dealers Conference, Peel Mining Ltd.: Kalgoorlie, Western Australia, 2018.

5. Downes, P.M.; Tilley, D.B.; Fitzherbert, J.A.; Clissold, M.E. Regional metamorphism and the alteration response of selected Silurian to Devonian minerals systems in the Nymagee area, Central Lachlan Orogen, New South Wales: A Hylogger ${ }^{\mathrm{TM}}$ case study. Aust. J. Earth Sci. 2016, 63, 1027-1052.

6. Lawrie, K.C.; Hinman, M.C. Cobar-style polymetallic Au-Cu-Ag-Pb-Zn deposits. J. Austral. Geol. Geophys. 1998, $17,169-187$.

7. Fitzherbert, J.A.; Mawson, R.; Mathieson, D.; Simpson, A.J.; Simpson, C.J.; Nelson, M.D. Metamorphism in the Cobar Basin: Current state of understanding and implications for mineralization. Q. Notes Geol. Surv. N. S. W. 2017, 148, 1-35.

8. Aurelia Metals Ltd. Federation Exploration Update. 13 August 2020 ASX Announcement. 2020. Available online: https://www2.asx.com.au/markets/trade-our-cash-market/announcements.ami (accessed on 20 October 2020).

9. David, V. Structural Setting of Mineral Deposits in the Cobar Basin. Ph.D. Thesis, University of New England, Armidale, NSW, Australia, 2005.

10. Downes, P.M.; Poulson, S.R. Isotope signatures of selected Silurian to Devonian mineral systems in the Nymagee area, central Lachlan Orogen, New South Wales. Q. Notes Geol. Surv. N. S. W. 2018, 151, 17-18.

11. Burrows, L. Comparison of the ore and Gangue Mineralogy and Metal Ratios for the Different ore Lenses of the Hera Mine, Central NSW. Bachelor's Thesis, UNSW, Sydney, NSW, Australia, 2017. 
12. Lay, A.; Graham, I.; Burrows, L.; McKinnon, A.; Privat, K. Ore and Gangue Minerals of the Hera Au-Pb-Zn-Ag Deposit, Cobar Basin, NSW. ASEG Ext. Abstracts 2018, 2018, 1-7.

13. Schellen, K. Comparison of the ore and Gangue Mineralogy for the Different ore Lenses of the Hera Mine, Central NSW; BEES0006 Report; UNSW: Sydney, NSW, Australia, 2020. 